See discussions, stats, and author profiles for this publication at: https://www.researchgate.net/publication/322221767

\title{
Nitrate Reductase, Micronutrients and Upland Rice Development as Influenced by Soil $\mathrm{pH}$ and Nitrogen Sources
}

Article in Communications in Soil Science and Plant Analysis · December 2017

DOI: 10.1080/00103624.2017.1416137

CITATIONS

2

6 authors, including:

Edemar Moro

Universidade do Oeste Paulista

34 PUBLICATIONS 181 CITATIONS

SEE PROFILE

Adriano Nascente

Brazilian Agricultural Research Corporation (EMBRAPA)

126 PUBLICATIONS 835 CITATIONS

SEE PROFILE

Some of the authors of this publication are also working on these related projects:

Nitrification in sugarcane soils View project

Project Práticas agrícolas sustentáveis para regiões tropicais de inverno seco View project
161

Carlos Alexandre Costa Crusciol

São Paulo State University

360 PUBLICATIONS 3,286 CITATIONS

SEE PROFILE

Heitor Cantarella

Instituto Agronômico de Campinas

250 PUBLICATIONS 2,838 CITATIONS

SEE PROFILE 


\title{
Communications in Soil Science and Plant Analysis
}

\section{Nitrate Reductase, Micronutrients and Upland Rice Development as Influenced by Soil pH and Nitrogen Sources}

\author{
Edemar Moro, Carlos Alexandre Costa Crusciol, Adriano Stephan Nascente, \\ Heitor Cantarella, Fernando Broetto \& Adriana Lima Moro
}

To cite this article: Edemar Moro, Carlos Alexandre Costa Crusciol, Adriano Stephan Nascente, Heitor Cantarella, Fernando Broetto \& Adriana Lima Moro (2017): Nitrate Reductase, Micronutrients and Upland Rice Development as Influenced by Soil pH and Nitrogen Sources, Communications in Soil Science and Plant Analysis

To link to this article: https://doi.org/10.1080/00103624.2017.1416137

\section{Published online: 20 Dec 2017.}

Submit your article to this journal $\sqsubset$

Џ Article views: 6

Q View related articles $\longleftarrow$

View Crossmark data ¿ 


\title{
Nitrate Reductase, Micronutrients and Upland Rice Development as Influenced by Soil pH and Nitrogen Sources
}

\author{
Edemar Moro $\mathbb{D}^{\mathrm{a}}$, Carlos Alexandre Costa Crusciol $\mathbb{D}^{\mathrm{b}}$, Adriano Stephan Nascente $\mathbb{D}^{\mathrm{c}}$, \\ Heitor Cantarella (10) ${ }^{d}$, Fernando Broetto (i) $^{\mathrm{e}}$, and Adriana Lima Moro (1) ${ }^{\mathrm{a}}$

\begin{abstract}
aDepartamento de Agronomia, Universidade do Oeste Paulista - UNOESTE, Campus II, Presidente Prudente, SP, Brazil; b'Faculdade de Ciências Agronômicas, Departamento de Produção Vegetal (Agricultura), Universidade Estadual Paulista (UNESP), Botucatu, SP, Brazil; 'Empresa Brasileira de Pesquisa Agropecuária (Embrapa Arroz e Feijão), Santo SP, Brazil; eDepartamento de Química e Bioquímica, Universidade Estadual Paulista (UNESP), Instituto de Biociências, Botucatu, SP, Brazil
\end{abstract} \\ Antônio de Goiás, GO, Brazil; 'Centro de Solos e Recursos Ambientais, Instituto Agronômico de Campinas, Campinas,
}

\begin{abstract}
The average yield of upland rice under no-tillage system (NTS), a sustainable soil management, is lower than in conventional tillage (one plowing and two disking). One of the reasons given for this drop in crop grain yield would be the low-nitrate assimilation capacity of rice seedlings, due to the low activity of the nitrate reductase (NR) enzyme in the early development phase. A greenhouse experiment was conducted to evaluate the effects of the soil acidic and nitrogen source in the micronutrient concentrations, NR activity and grain yield of upland rice growing under NTS. The soil used in the experiment was an Oxisol. The experimental design was completely randomized in a factorial $3 \times 4$. Treatments consisted of three levels of soil acidity (high, medium, and low) combined with four nitrogen sources (nitrate, ammonium, ammonium + nitrification inhibitor, and control - without $\mathrm{N}$ fertilization). The reduction of soil acidity reduced the concentration of zinc and manganese in rice plants. Generally, the activity of the NR enzyme was higher in plants grown in soils with low acidity and fertilized with calcium nitrate. There was a greater response in growth and yield in rice plants grown in soils with high acidity. Under medium acidity, rice plants grown with ammonium sulfate were more productive (no differences were detected with the addition of the nitrification inhibitor).
\end{abstract}

\section{ARTICLE HISTORY}

Received 30 January 2017

Accepted 5 December 2017

\section{KEYWORDS}

Ammonium; nitrate; Oryza

sativa; soil acidity; soil

fertility; yield

\section{Introduction}

Rice is one of the most cultivated cereals in the world, having great social and economic importance for many people. Cultivation in the upland environment is carried out in Asia (Saito et al. 2005), Africa (Oonyu 2011), and Americas (Nascente, Crusciol, and Cobucci 2013), and is increasing in worldwide importance due to water shortages for crop irrigation (Crusciol et al. 2013). In addition, it is important to grow this crop in a sustainable way, such as in no-tillage system (NTS) (Nascente et al. 2011a, 2011b).

However, upland rice grain yield at NTS is lower than in the conventional tillage (Crusciol et al. 2010; Kluthcouski et al. 2000). One explanation given for the decrease in crop grain yield would be the low-nitrate assimilation capacity of rice seedlings, due to the low activity of the nitrate reductase (NR) enzyme in the early development phase, prior to the tillering stage (Araújo et al. 2012). In experiments developed by D’Andréa et al. (2004), Nascente, Crusciol, and Cobucci (2012), and Araújo et al. (2012), it was verified that in NTS there is greater availability of $\mathrm{N}^{-\mathrm{NO}_{3}}{ }^{-}$in the soil 
regarding conventional tillage. Therefore, upland rice failure in NTS may be caused by the predominance of nitrate in the soil. Corroborating this information, Araújo et al. (2012) reported that rice presented better development when there were lower levels of nitrate and a higher amount of ammonium in the soil.

It is noteworthy that NR is an extremely important enzyme in the assimilation of $\mathrm{N}^{-\mathrm{NO}_{3}}{ }^{-}$by plants (Epstein and Bloom 2006). In this context, because rice came from a hydrophilic environment with a reduced environment, where ammonium prevails, it is likely that it is difficult for rice plants to synthesize NR enzyme in the first month of development, which may explain the low initial development of the crop when in the environment it prevails $\mathrm{N}-\mathrm{NO}_{3}{ }^{-}$, such as NTS (Fageria et al. 2014).

Moreover, in NTS due to surface correction of acidity, the content of some micronutrients such as copper $(\mathrm{Cu})$, manganese $(\mathrm{Mn})$, zinc $(\mathrm{Zn})$, and iron $(\mathrm{Fe})$ may decrease, the decrease of this last element may compromise the conversion of $\mathrm{NO}_{3}{ }^{-}$to $\mathrm{NO}_{2}{ }^{-}$, since $\mathrm{Fe}$ is essential for NR (Fageria et al. 2014). Therefore, the total nitrate reduction capacity of plants, including additional factors, depends on Fe (Campbell 1999).

One possibility to overcome this problem of low NR enzyme activity in the early rice development phase would be the use of $\mathrm{N}$ sources in the ammoniacal form at sowing and/or shortly after emergence. However, as $\mathrm{N}$-ammoniacal changes in $\mathrm{N}$-nitric in the soil occur rapidly, some strategy would be necessary, especially the use of nitrification inhibitors alongside the ammoniacal sources.

The hypothesis of this study was to understand how soil $\mathrm{pH}$ and nitrogen fertilizer sources affect NR activity, micronutrient uptake, and upland rice grain yield at NTS. The objective of this work was to evaluate the effects of the acidity of soil and nitrogen sources on micronutrient content, NR enzyme activity, yield components, and grain yield of upland rice growing under NTS.

\section{Material and methods}

The experiment was conducted in greenhouse conditions at the Department of Plant Production of the Faculty of Agronomic Sciences/Unesp, Campus de Botucatu-SP, Brazil (22 $51^{\prime} \mathrm{S}, 48^{\circ} 26^{\prime} \mathrm{W}$, $815 \mathrm{~m}$ of altitude). The soil (0.00-0.20 m layer) used in the experiment was classified as Oxison (red Latosol according to Brazilian soil classification system), presenting 630, 90 and $280 \mathrm{~g} \mathrm{~kg}^{-1}$ of sand, silt and clay, respectively, from an NTS of 10 years. The soil collected was divided into three equal parts. One portion was maintained at the original $\mathrm{pH}$ and in the other two the $\mathrm{pH}$ was raised to 5.5 and 6.3. For the elevation of the $\mathrm{pH}$, the dolomitic limestone, composed of $33 \% \mathrm{CaO}$ and $16 \%$ of $\mathrm{MgO}$, was used and the required amount was determined by the incubation method (30 days). The determined amounts of limestone were applied to the soil portions, which remained in incubation for 30 days, with moisture at the maximum water retention capacity of the soil, for corrective reaction. The chemical characteristics of the soil were evaluated before incubation and after 30 days, following the methodology proposed by Bvan et al. (2001) (Table 1).

The soil portions were subjected to a wash, with a goal to force leach $\mathrm{NO}_{3}{ }^{-}$, which could possibly be greater in the soil portions that had received liming. The leaching of $\mathrm{NO}_{3}{ }^{-}$was carried out in $17 \mathrm{~L}$ pots by the addition of water. The volume of water used was twice the water retention capacity of the soil. After the leaching process the nitrate contents removed were 4.5 and $9.45 \mathrm{mg} \mathrm{dm}^{-3}$ of soil, for pH 5.5 and 6.3, respectively.

The soil was removed from the pots, dried in the shade and each soil portion was fertilized with $150 \mathrm{mg}$ $\mathrm{dm}^{-3}$ of $\mathrm{P}$ and $80 \mathrm{mg} \mathrm{dm}{ }^{-3}$ of $\mathrm{K}$ in the forms of triple superphosphate and potassium chloride, respectively. The micronutrients were applied after the germination of the plants along with the replacement of water in the pots. The amounts applied were: $2.0 \mathrm{mg} \mathrm{dm}^{-3} \mathrm{~B}, 3.0 \mathrm{mg} \mathrm{dm}^{-3} \mathrm{Mn}, 10.0 \mathrm{mg} \mathrm{dm}^{-3} \mathrm{Zn}$ and $1.5 \mathrm{mg} \mathrm{dm}{ }^{-3} \mathrm{Cu}$, provided in the forms of $\mathrm{H}_{3} \mathrm{BO}_{3}, \mathrm{MnSO}_{4}, \mathrm{ZnSO}_{4}$ and $\mathrm{CuSO}_{4}$, respectively.

The experimental design was completely randomized in the $3 \times 4$ factorial scheme, with four replications. The treatments were composed of three levels of acidity $(\mathrm{pH} \mathrm{CaCl})$ of the soil (high $\mathrm{pH}=4.5$, medium $-\mathrm{pH}=5.5$ and low $-\mathrm{pH}=6.3)$ with sources of $\mathrm{N}\left(1-\right.$ nitric $-\mathrm{Ca}\left(\mathrm{NO}_{3}\right) 2.4 \mathrm{H}_{2} \mathrm{O}, 2$ - ammoniacal - $\left(\mathrm{NH}_{4}\right)_{2} \mathrm{SO}_{4}, 3$ - ammoniacal + nitrification inhibitor - DCD (dicyandiamide) and 4 - control - without $\mathrm{N}$ ). The amount of $\mathrm{N}$ applied, regardless of source, was $80 \mathrm{mg} \mathrm{dm}^{-3}$ of soil. The 
Table 1. Soil chemical attributes before liming incubation and 30 days after. Botucatu-SP, Brazil.

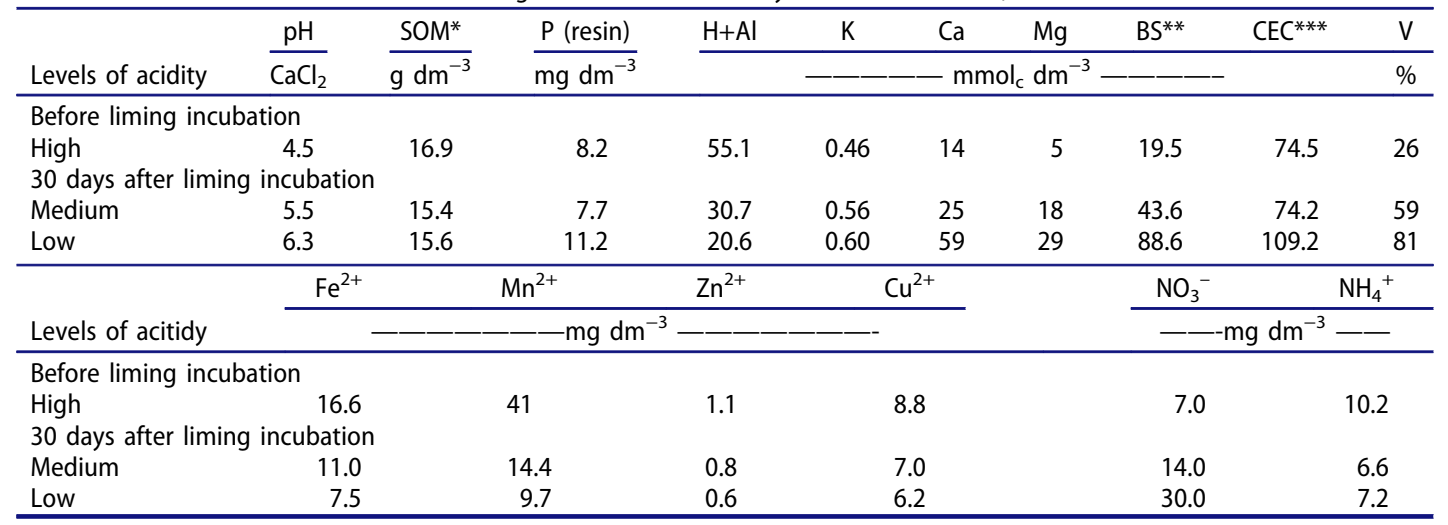

${ }^{*} \mathrm{SOM}$ - soil organic matter. ${ }^{* *} \mathrm{BS}$ - Base saturation. ${ }^{* * *} \mathrm{CEC}$ - cation exchange capacity.

experimental units were constituted by plastic pots with $17 \mathrm{~kg}$ capacity, completely filled with soil. Twenty seeds of rice were sown per pot (cultivar IAC-47) and, after germination, 10 plants were maintained. The amount of $\mathrm{N}$ provided by the nitric, ammonium, and ammonium + DCD source was divided twice, half immediately after the emergence of the rice, and the remainder at 15 days after the first, applied to the soil surface. Soil moisture throughout the experiment was monitored daily by weighing each pot, and the replacement of evapotranspirated water occurred when it reached $85 \%$, increasing to $100 \%$ of the field capacity.

Soil sampling was performed at 7 and 28 days after emergence (DAE). The soil was collected at four points per pots to form a composite sample, and then the samples were kept in an ice box until the chemical analysis, that was completed on the same day of sampling. The levels of $\mathrm{NO}^{-}$and $\mathrm{NH}_{4}{ }^{+}$in the soil were determined by the method proposed by Silva (1999).

Plant sampling was performed at 7 and 28 DAE. Thus, two plants per pot were harvested, and plant shoots were dried in an oven, ground and analyzed for micronutrient content $(\mathrm{Fe}, \mathrm{Zn}, \mathrm{Cu}$, and Mn) (Malavolta, Vitti, and Oliveira 1997).

The leaves for the determination of the enzyme NR were sampled at random. Four newly expanded leaves were collected in each pot, and the middle third was removed for evaluation. The leaves were collected in the morning between 8:00 am and 10:00 am and analyzed on the same sampling day following the methodology described by Jaworski (1971).

The number of panicles per plant was obtained by counting the panicles of two plants per pot. In these panicles, the total number of spikelets per panicle was counted accordingly and also the fertility of the spikelets and the grain yield of the rice was evaluated. The values presented for these variables correspond to the average of the two plants. The fertility of the spikelets was determined by the ratio of the number of spikelets per panicle to the total number of spikelets per panicle $\mathrm{x} 100$. The mass of 100 grains was obtained by averaging four samples of 100 grains per experimental unit. The water contents of the grains were determined and adjusted to $130 \mathrm{~g} \mathrm{~kg}^{-1}$. The track of the panicles was completed manually. The material passed through the cleaning process for the separation of the straw and the spikelets, of the spikelets grenades. After completing this process, the grains were weighed and then the productivity in grams per plant $\left(130 \mathrm{~g} \mathrm{~kg}^{-1}\right)$ was calculated.

The data were submitted for analysis of variance and the means compared by the least significant difference (LSD) test $(p \leq 0.05)$.

\section{Results and discussion}

In the analysis of the results, it was possible to observe that at $7 \mathrm{DAE}$ the soil ammonium content was not influenced by the soil acidity (Table 2). In the interaction, it was observed that, at each level 
Table 2. Ammonium content in the soil at 7 and 28 days after emergence (DAE) of upland rice as a function of levels of soil acidity and source of nitrogen fertilization. Botucatu-SP, Brazil.

\begin{tabular}{|c|c|c|c|c|c|}
\hline \multirow[b]{3}{*}{$\begin{array}{l}\text { Levels } \\
\text { of acidity }\end{array}$} & \multicolumn{4}{|c|}{ Sources of nitrogen fertilization } & \multirow[b]{3}{*}{ Average } \\
\hline & Control & $\mathrm{NO}_{3}^{-}$ & $\mathrm{NH}_{4}^{+}$ & $\mathrm{NH}_{4}^{+}+\mathrm{DCD}^{1}$ & \\
\hline & \multicolumn{4}{|c|}{ 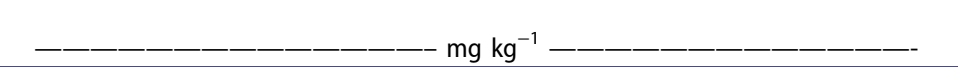 } & \\
\hline \multicolumn{6}{|l|}{$7 \mathrm{DAE}$} \\
\hline High & $14.6 \mathrm{aB}$ & $4.2 \mathrm{aC}$ & $28.0 \mathrm{aA}$ & $30.0 \mathrm{aA}$ & $19.2 \mathrm{a}$ \\
\hline Medium & $18.0 \mathrm{aB}$ & $2.2 \mathrm{aC}$ & $28.3 \mathrm{aA}$ & $28.6 \mathrm{aA}$ & $19.3 \mathrm{a}$ \\
\hline Low & $16.0 \mathrm{aC}$ & $2.7 \mathrm{aD}$ & $26.7 \mathrm{aB}$ & $32.0 \mathrm{aA}$ & $19.4 \mathrm{a}$ \\
\hline \multicolumn{6}{|l|}{$28 \mathrm{DAE}$} \\
\hline High & $4.4 \mathrm{bB}$ & $5.2 \mathrm{aB}$ & $21.4 \mathrm{aA}$ & $21.2 \mathrm{aA}$ & $13.1 \mathrm{a}$ \\
\hline Medium & $8.8 \mathrm{aB}$ & $5.0 \mathrm{aC}$ & $22.4 \mathrm{aA}$ & $21.9 \mathrm{aA}$ & $14.5 \mathrm{a}$ \\
\hline Low & $5.6 \mathrm{bB}$ & $6.5 \mathrm{aB}$ & $22.0 \mathrm{aA}$ & $22.2 \mathrm{aA}$ & $14.1 \mathrm{a}$ \\
\hline Average & $9.0 \mathrm{~B}$ & $5.2 \mathrm{C}$ & $26.2 \mathrm{~A}$ & $27.6 \mathrm{~A}$ & - \\
\hline
\end{tabular}

${ }^{1}$ DCD: dicyanodiamide - nitrification inhibitor. Means followed by the same letter, lowercase in the columns and uppercase in the lines do not differ by the LSD test $(p \leq 0.05)$.

of soil acidity, the ammoniacal sources exceeded the control and the nitric source. It should be noted that that the soil ammonium content was higher with the ammonia source and with the nitrification inhibitor (DCD) at all acid levels, but at the low acid level the application of the DCD inhibited nitrification, maintaining a higher amount of $\mathrm{N}$ in the ammoniacal form for a longer time, in relation to treatment with ammoniacal source only. According to Fageria (2000), nitrification rate in acidic soils is reduced, since it directly affects the population of nitrifying bacteria, and the nitrate levels in the soil fall rapidly at $\mathrm{pH}$ values lower than 6.0, becoming quite reduced in soil with $\mathrm{pH}$ below 5.0 (Crusciol et al. 2011).

At $28 \mathrm{DAE}$, the effect of acidity on the soil $\mathrm{NH}_{4}{ }^{+}$contents was observed only for the control, and the highest content was observed for the average acidity ( $\mathrm{pH}$ 5.5). Furthermore, it was observed, in the average of all the evaluations, that there was no effect of the soil acidity on the soil ammonium contents. As for the sources, it also verified higher levels of ammonium in the soil in the treatments with ammonia and $\mathrm{NH}_{4}{ }^{+}+\mathrm{DCD}$. This result was expected, since the application of ammoniacal sources gives rise to soil ammonium content (Fageria 2014).

Soil nitrate contents were influenced by soil acidity (Table 3). In general, in all soil samples, the highest values were observed in conditions of low acidity. According to Flowers and O'callaghan (1983), raising the $\mathrm{pH}$ promotes the increase of nitrification. This is because the higher $\mathrm{pH}$ provides more suitable conditions for autotrophic nitrification.

Moreover, with the data of each acid level, we observed that at 7 DAE, in all samples nitrate source provided the highest levels of soil nitrate. On the other hand, under conditions of low acidity, the

Table 3. Nitrate content in the soil at 7 and 28 days after emergence (DAE) of upland rice as a function of levels of soil acidity and source of nitrogen fertilization. Botucatu-SP, Brazil.

\begin{tabular}{|c|c|c|c|c|c|}
\hline \multirow[b]{3}{*}{$\begin{array}{l}\text { Levels } \\
\text { of acidity }\end{array}$} & \multicolumn{4}{|c|}{ Sources of nitrogen fertilization } & \multirow[b]{3}{*}{ Average } \\
\hline & Control & $\mathrm{NO}_{3}^{-}$ & $\mathrm{NH}_{4}^{+}$ & $\mathrm{NH}_{4}{ }^{+}+\mathrm{DCD}^{1}$ & \\
\hline & \multicolumn{4}{|c|}{ 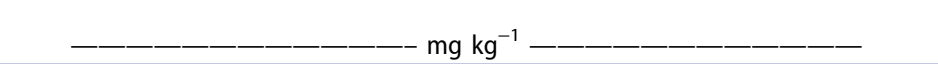 } & \\
\hline \multicolumn{6}{|l|}{$7 \mathrm{DAE}$} \\
\hline High & $20.8 \mathrm{cB}$ & $33.2 \mathrm{bA}$ & $16.6 \mathrm{aC}$ & $19.1 \mathrm{cB}$ & $22.4 \mathrm{~b}$ \\
\hline Medium & $26.1 \mathrm{aA}$ & $27.0 \mathrm{cA}$ & $16.8 \mathrm{aC}$ & $22.5 \mathrm{bB}$ & $23.1 \mathrm{~b}$ \\
\hline \multicolumn{5}{|l|}{$28 \mathrm{DAE}$} & $27.0 \mathrm{a}$ \\
\hline High & $1.9 \mathrm{bC}$ & $19.7 \mathrm{bA}$ & $7.2 \mathrm{bB}$ & $6.6 \mathrm{CB}$ & $8.8 \mathrm{~b}$ \\
\hline Medium & $4.2 \mathrm{aC}$ & $18.8 \mathrm{bA}$ & $5.4 \mathrm{cC}$ & $9.1 \mathrm{bB}$ & $9.4 \mathrm{~b}$ \\
\hline Low & $4.8 \mathrm{aC}$ & $34.8 \mathrm{aA}$ & $18.2 \mathrm{aB}$ & $25.5 \mathrm{aA}$ & $20.8 \mathrm{a}$ \\
\hline Average & 10.8 & 33.0 & 15.7 & 19.3 & - \\
\hline
\end{tabular}

${ }^{1} \mathrm{DCD}$ : dicyanodiamide - nitrification inhibitor. Means followed by the same letter, lowercase in the columns and uppercase in the lines do not differ by the LSD test $(p \leq 0.05)$. 
application of $\mathrm{NH}_{4}{ }^{+}$and $\mathrm{NH}_{4}{ }^{+}+\mathrm{DCD}$ reduced the nitrification process, giving lower levels in relation to the treatment with nitrate source. However, at $28 \mathrm{DAE}$, these same treatments, mainly $\mathrm{NH}_{4}{ }^{+}+\mathrm{DCD}$, were not sufficient to prevent nitrification as values similar to the treatment with $\mathrm{NO}_{3}{ }^{-}$application.

Regarding micronutrients, it was verified that the copper content $(\mathrm{Cu})$ was influenced by the soil acidity only in the control treatment, in which the contents were lower at low acidity (Table 4). It was verified that $\mathrm{Cu}$ contents were higher with the use of ammoniacal sources at all levels of acidity. According to Fageria (2000), ammonium sulfate causes soil $\mathrm{pH}$ reduction. In addition, acidification by nitrogen fertilization increases the availability of $\mathrm{Cu}$ and $\mathrm{Zn}$ in the soil due to the higher solubility of these micronutrients when $\mathrm{pH}$ reduction occurs (Lange et al. 2006). This explains the lower content of $\mathrm{Cu}$ for the nitric source and higher content for the ammoniacal sources.

Zinc contents were influenced by soil acidity, and the highest values were observed under conditions of high soil acidity (Table 4). The $\mathrm{Zn}$ levels in the plant decreased significantly with increasing soil $\mathrm{pH}$, which may be related to the adsorption or precipitation of this micronutrient. There is a decrease in the accumulation of $\mathrm{Fe}, \mathrm{Mn}$, and $\mathrm{Zn}$ with soil $\mathrm{pH}$ elevation above 5.5 (Fageria 2000). Zn availability decreases about 100 times with increasing one $\mathrm{pH}$ unit (Tisdale, Nelson, and Beaton 1985). According to Fageria, Slaton, and Baligar (2003), the adequate level of $\mathrm{Zn}$ in the rice shoots is $47 \mathrm{mg} \mathrm{kg}^{-1}$. In the present work, the values of $\mathrm{Zn}$ were close to this value in conditions of high acidity. It was verified high content of $\mathrm{Zn}$ in the rice leaves when using $\mathrm{N}$ fertilizer in ammoniacal source without the inhibitor and in conditions of low acidity of the soil. This may have occurred because of the effect of ammonium sulfate on reducing the $\mathrm{pH}$ as discussed for $\mathrm{Cu}$. In conditions of medium acidity, the contents of $\mathrm{Zn}$ were higher with the application of ammoniac sources of $\mathrm{N}$.

The iron contents (Fe) were influenced by the soil acidity (Table 4); however, they were not by $\mathrm{N}$ sources. The difference between $\mathrm{N}$ sources for medium and high acidity was small. However, for these levels of acidity all the sources provided higher Fe contents than the control.

The manganese content (Mn) was higher when the soil acidity was high (Table 4). This behavior occurred for all sources of $\mathrm{N}$. The lowest values for Mn were observed when the soil acidity was

Table 4. Copper, zinc, iron and manganese content in the rice shoots at 28 days after emergence (DAE) as a function of levels of soil acidity and source of nitrogen fertilization. Botucatu-SP, Brazil.

\begin{tabular}{|c|c|c|c|c|c|}
\hline \multirow[b]{3}{*}{$\begin{array}{l}\text { Levels } \\
\text { of acidity }\end{array}$} & \multicolumn{4}{|c|}{ Source of nitrogen fertilization } & \multirow[b]{3}{*}{ Average } \\
\hline & Control & $\mathrm{NO}_{3}^{-}$ & $\mathrm{NH}_{4}^{+}$ & $\mathrm{NH}_{4}^{+}+\mathrm{DCD}^{1}$ & \\
\hline & \multicolumn{4}{|c|}{ ——————————- $\mathrm{mg} \mathrm{kg}^{-1}$-—————————— } & \\
\hline \multicolumn{6}{|l|}{ Copper } \\
\hline High & $17.8 \mathrm{aB}$ & $17.3 \mathrm{aB}$ & $22.0 \mathrm{aA}$ & $21.5 \mathrm{aA}$ & $19.7 \mathrm{a}$ \\
\hline Medium & $16.5 \mathrm{aB}$ & $15.0 \mathrm{aB}$ & $21.3 \mathrm{aA}$ & $19.3 \mathrm{aA}$ & $17.3 \mathrm{a}$ \\
\hline Low & $13.5 \mathrm{bB}$ & $16.0 \mathrm{aB}$ & $21.0 \mathrm{aA}$ & $21.8 \mathrm{aA}$ & $18.8 \mathrm{a}$ \\
\hline Average & $15.9 \mathrm{~B}$ & $16.1 \mathrm{~B}$ & $21.4 \mathrm{~A}$ & $20.9 \mathrm{~A}$ & 18.6 \\
\hline \multicolumn{6}{|l|}{ Zinc } \\
\hline High & $41.8 \mathrm{aA}$ & $38.0 \mathrm{aB}$ & $45.3 \mathrm{aA}$ & $42.3 \mathrm{aA}$ & $42.0 \mathrm{a}$ \\
\hline Medium & $22.8 \mathrm{bB}$ & $23.8 \mathrm{bB}$ & $36.3 \mathrm{bA}$ & $32.3 \mathrm{bA}$ & $29.0 \mathrm{~b}$ \\
\hline Low & $14.3 \mathrm{cC}$ & $23.0 \mathrm{bB}$ & $32.0 \mathrm{bA}$ & $26.5 \mathrm{cB}$ & $24.0 \mathrm{c}$ \\
\hline Average & $26.3 \mathrm{~A}$ & $28.3 \mathrm{~A}$ & $15.9 \mathrm{~B}$ & $15.9 \mathrm{~B}$ & 31.7 \\
\hline \multicolumn{6}{|l|}{ Iron } \\
\hline High & $121 \mathrm{aB}$ & $127 \mathrm{bAB}$ & $124 \mathrm{CAB}$ & $133 \mathrm{bA}$ & $126 \mathrm{~b}$ \\
\hline Medium & $125 \mathrm{aB}$ & $143 \mathrm{aA}$ & $143 \mathrm{bA}$ & $95 \mathrm{cC}$ & $127 \mathrm{~b}$ \\
\hline Low & $116 \mathrm{aC}$ & $110 \mathrm{cC}$ & $177 \mathrm{aB}$ & $220 \mathrm{aA}$ & $156 a$ \\
\hline Average & $121 \mathrm{~B}$ & $127 \mathrm{~B}$ & $148 \mathrm{~A}$ & $149 \mathrm{~A}$ & 136 \\
\hline \multicolumn{6}{|c|}{ Manganese } \\
\hline High & $496 \mathrm{aA}$ & $514 \mathrm{aA}$ & $457 \mathrm{aB}$ & $443 \mathrm{aB}$ & $478 \mathrm{a}$ \\
\hline Medium & $43 \mathrm{aB}$ & $79 \mathrm{bA}$ & $84 \mathrm{bA}$ & $85 \mathrm{bA}$ & $73 \mathrm{~b}$ \\
\hline Low & $35 \mathrm{aB}$ & $47 \mathrm{CB}$ & $81 \mathrm{bA}$ & $57 \mathrm{cB}$ & $55 \mathrm{c}$ \\
\hline Average & 191 B & $213 \mathrm{~A}$ & $207 \mathrm{~A}$ & $195 \mathrm{AB}$ & 202 \\
\hline
\end{tabular}

${ }^{1} D C D$ : dicyanodiamide - nitrification inhibitor. Means followed by the same letter, lowercase in the columns and uppercase in the lines do not differ by the LSD test $(p \leq 0.05)$. 
medium or low. In addition, it was found that there was no standard behavior for the different $\mathrm{N}$ sources.

In relation to NR enzyme activity, it was found that in the 7 DAE there was a difference between the level of acidity and the use of the nitrate source (Table 5). For this source, the highest activity was observed under conditions of low and medium acidity. It was also observed that in the three levels of acidity, the enzymatic activity of the control pot was equal to or higher than the $\mathrm{N}$ sources. At 28 $\mathrm{DAE}$, it was observed that the low acidity provided higher $\mathrm{NR}$ activity in relation to all $\mathrm{N}$ sources. Nitric source, in most of the results, provided a higher NR activity regardless of the level of acidity.

Thus, the hypothesis that NR activity would be lower in the early phase of rice development was not confirmed (Table 5). This can be explained by the reduction of nitrate levels in the soil (Table 3). Similar results were obtained by Celestino (2006), who observed a reduction in the NR activity with the development of the rice crop in the absence of nitrogen fertilization, noting that the NR enzyme activity in the leaves and roots can be induced by the presence of the substrate $\left(\mathrm{NO}_{3}{ }^{-}\right)$. The maximum activity of $\mathrm{NR}$ was in the period of greatest availability of $\mathrm{NO}_{3}{ }^{-}$similar results was achieved by Pacheco et al. (2011).

In addition, higher NR activity (Table 5) also occurred with increasing $\mathrm{pH}$ (low acidity) due to the higher nitrate content in the soil (Table 3). The results of the study showed that $\mathrm{N}$-nitric acid levels were higher in the soil than in the $\mathrm{N}$-nitric acid. The availability of nitrate can positively interfere with the increase in NR activity, since it is the substrate of the enzyme (Crawford 1995). The data justify the higher activity of the NR with the application of the nitric source.

The number of panicles per plant was influenced by soil acidity only when $\mathrm{N}$ was applied (Table 6). The highest values for this yield component were observed under conditions of high acidity. These values were equal to mean acidity only when the source was the ammoniacal + nitrification inhibitor. With the exception of the control and the nitric source, the lowest number of panicles per plant was observed under conditions of low soil acidity. It was observed that the ammoniacal exceeds the nitrate and the control independently of the acidity of the soil.

The number of spikelets per panicle was not altered by soil acidity (Table 6). Concerning the fertility of the spikelets, the lowest value was observed for the low acidity, when the $\mathrm{N}$ source used was the nitrate (Table 6). The other values did not differ significantly. We observed the effect of the sources only concerning low acidity. The values for the ammoniacal sources were superior to the control and the nitric source.

The mass of 100 grains was influenced by the acidity only in the control and nitric source (Table 6). In the control, the greater mass of 100 grains was observed in conditions of high acidity. When the nitrate source was used, in the condition of high and medium acidity, the values were higher than the low acidity of the soil. It was observed that, for the high acidity, the treatments did

Table 5. Nitrate reductase (NR) enzyme activity in rice leaves at rice shoots at 7 and 28 days after emergence (DAE) as a function of levels of soil acidity and source of nitrogen fertilization. Botucatu-SP, Brazil.

\begin{tabular}{|c|c|c|c|c|c|}
\hline \multirow[b]{3}{*}{$\begin{array}{l}\text { Levels } \\
\text { of acidity }\end{array}$} & \multicolumn{4}{|c|}{ Sources of nitrogen fertilization } & \multirow[b]{3}{*}{ Average } \\
\hline & Control & $\mathrm{NO}_{3}^{-}$ & $\mathrm{NH}_{4}^{+}$ & $\mathrm{NH}_{4}^{+}+\mathrm{DCD}^{1}$ & \\
\hline & \multicolumn{4}{|c|}{${ }^{2} \mathrm{NO}_{2}^{-}\left(\mu \mathrm{mol} \mathrm{g}{ }^{-1}\right.$ of fresh material $\left.\mathrm{h}^{-1}\right)$} & \\
\hline \multicolumn{6}{|l|}{$7 \mathrm{DAE}$} \\
\hline High & $12.1 \mathrm{aA}$ & $10.7 \mathrm{bAB}$ & $11.3 \mathrm{aAB}$ & $10.1 \mathrm{aB}$ & $11.0 \mathrm{~b}$ \\
\hline Medium & $13.3 \mathrm{aA}$ & $12.6 \mathrm{aAB}$ & $11.4 \mathrm{aB}$ & $11.4 \mathrm{aB}$ & $12.0 \mathrm{a}$ \\
\hline Low & $12.2 \mathrm{aA}$ & $12.9 \mathrm{aA}$ & $11.9 \mathrm{aA}$ & $11.5 \mathrm{aA}$ & $12.0 \mathrm{a}$ \\
\hline \multicolumn{6}{|l|}{$28 \mathrm{DAE}$} \\
\hline High & $1.6 \mathrm{cB}$ & $3.8 \mathrm{cA}$ & $2.2 \mathrm{cB}$ & $2.3 \mathrm{cB}$ & $2.5 \mathrm{c}$ \\
\hline Medium & $2.8 \mathrm{bD}$ & $6.6 \mathrm{bA}$ & $4.0 \mathrm{bC}$ & $5.2 \mathrm{bB}$ & $5.0 \mathrm{~b}$ \\
\hline Low & $5.4 \mathrm{aB}$ & $9.8 \mathrm{aA}$ & $5.5 \mathrm{aB}$ & $6.3 \mathrm{aB}$ & $7.0 \mathrm{a}$ \\
\hline Average & 8.6 & 10.0 & 7.9 & 7.8 & - \\
\hline
\end{tabular}

${ }^{1} \mathrm{DCD}$ : dicyandiamide - nitrification inhibitor. The activity of NR is expressed by the amount of nitrite $\left(\mathrm{NO}_{2}^{-}\right)$formed. Means followed by the same letter, lowercase in the columns and uppercase in the lines do not differ by the LSD test $(p \leq 0.05)$. 
Table 6. Yield components and yield of upland rice as a function of soil acidity levels and nitrogen fertilization sources. BotucatuSP, Brazil.

\begin{tabular}{|c|c|c|c|c|c|}
\hline \multirow{2}{*}{$\begin{array}{l}\text { Levels } \\
\text { of acidity }\end{array}$} & \multicolumn{4}{|c|}{ Sources of nitrogen fertilization } & \multirow[b]{2}{*}{ Average } \\
\hline & Control & $\mathrm{NO}_{3}^{-}$ & $\mathrm{NH}_{4}^{+}$ & $\mathrm{NH}_{4}^{+}+\mathrm{DCD}^{1}$ & \\
\hline & \multicolumn{5}{|c|}{ Panicles (n..$^{\circ}$ plant $^{-1}$ ) } \\
\hline High & $4 \mathrm{aC}$ & $9 \mathrm{aB}$ & $11 \mathrm{Aa}$ & $10 \mathrm{aAB}$ & $8.5 \mathrm{a}$ \\
\hline Medium & $5 \mathrm{aC}$ & $6 \mathrm{bC}$ & $9 \mathrm{bB}$ & $11 \mathrm{aA}$ & $7.7 \mathrm{~b}$ \\
\hline Low & $4 \mathrm{aC}$ & $5 \mathrm{bC}$ & $7 \mathrm{cB}$ & $8 \mathrm{bA}$ & $6.0 \mathrm{c}$ \\
\hline \multirow[t]{2}{*}{ Average } & $4.0 \mathrm{D}$ & $7.0 \mathrm{C}$ & $9.0 \mathrm{~B}$ & $10.0 \mathrm{~A}$ & \\
\hline & \multicolumn{5}{|c|}{ Spikelets (n. ${ }^{\circ}$ per panicles) } \\
\hline High & $55 \mathrm{aA}$ & $64 \mathrm{aA}$ & $60 \mathrm{aA}$ & $65 \mathrm{aA}$ & $61 \mathrm{a}$ \\
\hline Medium & $60 \mathrm{aA}$ & $66 \mathrm{aA}$ & $62 \mathrm{aA}$ & $60 \mathrm{aA}$ & $62 \mathrm{a}$ \\
\hline Low & $54 \mathrm{aA}$ & $60 \mathrm{aA}$ & $63 \mathrm{aA}$ & $60 \mathrm{aA}$ & $59 \mathrm{a}$ \\
\hline \multirow[t]{2}{*}{ Average } & $56 \mathrm{~B}$ & $63 \mathrm{~A}$ & $62 \mathrm{~A}$ & $62 \mathrm{~A}$ & \\
\hline & \multicolumn{5}{|c|}{ Spikelets fertility (\%) } \\
\hline High & $83 \mathrm{aA}$ & $88 \mathrm{aA}$ & $79 \mathrm{aA}$ & $81 \mathrm{aA}$ & $83 \mathrm{a}$ \\
\hline Medium & $78 \mathrm{aA}$ & $86 \mathrm{aA}$ & $86 \mathrm{aA}$ & $86 \mathrm{aA}$ & $84 \mathrm{a}$ \\
\hline Low & $72 \mathrm{aB}$ & $64 \mathrm{bB}$ & $88 \mathrm{aA}$ & $86 \mathrm{aA}$ & $78 \mathrm{a}$ \\
\hline \multirow{2}{*}{ Average } & $78 \mathrm{~A}$ & $79 \mathrm{~A}$ & $84 \mathrm{~A}$ & $84 \mathrm{~A}$ & \\
\hline & \multicolumn{5}{|c|}{ Mass of 100 seeds (grams) } \\
\hline High & $3.0 \mathrm{aA}$ & $3.1 \mathrm{aA}$ & $3.0 \mathrm{aA}$ & $3.1 \mathrm{aA}$ & $3.0 \mathrm{a}$ \\
\hline Medium & $2.7 \mathrm{bB}$ & $2.9 \mathrm{aAB}$ & $3.1 \mathrm{aA}$ & $3.0 \mathrm{aA}$ & $2.9 \mathrm{~b}$ \\
\hline Low & $2.7 \mathrm{bAB}$ & $2.5 \mathrm{bB}$ & $3.0 \mathrm{aA}$ & $3.0 \mathrm{aA}$ & $2.8 \mathrm{~b}$ \\
\hline \multirow[t]{2}{*}{ Average } & $2.8 \mathrm{~b}$ & $2.5 \mathrm{~b}$ & $3.0 \mathrm{~A}$ & $3.0 \mathrm{~A}$ & \\
\hline & \multicolumn{5}{|c|}{ Grain yield (g plant ${ }^{-1}$ ) } \\
\hline High & $6 \mathrm{aB}$ & $15 \mathrm{aA}$ & $15 \mathrm{aA}$ & $16 \mathrm{aA}$ & $13 \mathrm{a}$ \\
\hline Medium & $6 \mathrm{aC}$ & $10 \mathrm{bB}$ & $15 \mathrm{aA}$ & $17 \mathrm{aA}$ & $12 \mathrm{a}$ \\
\hline Low & $5 \mathrm{aB}$ & $5 \mathrm{CB}$ & $11 \mathrm{bA}$ & $13 \mathrm{bA}$ & $8.5 \mathrm{~b}$ \\
\hline Average & $5.6 \mathrm{C}$ & $10.0 \mathrm{~B}$ & $13.7 \mathrm{~A}$ & $15.3 \mathrm{~A}$ & - \\
\hline
\end{tabular}

not influence the results. For the low and medium acidity, the highest values were obtained with the ammoniacal sources.

The grain yield was not influenced by the soil acidity, only in the control treatment (Table 6). With the addition of nitrogen, the average and high acidity provided the highest values, with the exception of the medium acidity for the nitrate source. Ammoniacal sources surpassed the others treatments. Another exception was the nitric source in conditions of high acidity of the soil that provided productivity equal to the ammoniacal sources.

Increasing $\mathrm{pH}$ above 5.3 causes a decrease in rice yield (Fageria 2000). Moreover, Fageria, Moreira, and Coelho (2011) showed rice yield reduction when soil $\mathrm{pH}$ increased from 4.6 to 6.8. Rice adapted to the upland ecosystem is best developed with the supply of nitrate and ammonium in similar quantities ( $\mathrm{Ta}$ and Ohira 1981). Therefore, the negative influence of the $\mathrm{pH}$ increases on the yield and yield components may be associated with the imbalance of the $\mathrm{NO}_{3}{ }^{-} / \mathrm{NH}_{4}{ }^{+}$ratio, since the $\mathrm{NH}_{4}{ }^{+}$supply improved crop performance. In addition, the roots are known to be responsible for most of the $\mathrm{N}$ uptake; however, not all parts of the roots are efficient to uptake nutrients, like $\mathrm{N}$. The most efficient part of the root is the zone of absorbent hairs, which is only present in new roots (Fageria 2014). Therefore, the high-to-medium $\mathrm{pH}$ was not a problem for the root development and allowed growing new roots, which was important to uptake $\mathrm{N}$ and allow increasing grain yield. According to Fageria (2014), $\mathrm{N}$ is one of the most important nutrients for root growing.

Nitrogen is a nutrient very important for rice development. In this sense, our results showed that the absence of $\mathrm{N}$ fertilization resulted in reduction of upland rice grain yield. It should be emphasized that the cultivar used had better yields under conditions of medium and high acidity. Corroborating this information, Fageria, Moreira, and Coelho (2011) cited that rice is an acidtolerant plant and its growth was linearly increased when Al saturation in the Brazilian Oxisol soil was increased from 0 to $30 \%$. Our data allow infering that in the NTS when pH increases to levels above 5.5 seems to be harmful to the rice development . Besides, this result reinforce the theory that 
rice develops better in environments with a low nitrate and high ammonium content in the soil, which is found in low soil $\mathrm{pH}$. This increase in $\mathrm{pH}$ also resulted in lower absorption of $\mathrm{Zn}$ and $\mathrm{Mn}$ (Table 4) which are important nutrients for crop development (Fageria 2000). On the other hand, it favored the higher activity of the NR enzyme, which may be related to the higher availability of nitrate. According to Galangau, Daniel-Vedele, and Moureaux (1988) and Vincentz, Moureaux, and Leydecker (1993), the NR enzyme activity in leaves and roots can be induced by the presence of the substrate $\left(\mathrm{NO}_{3}{ }^{-}\right)$, although this higher activity did not translate into higher grain yield.

Furthermore, rice grain yield occurs due to differences in assimilate distribution between the organs during plant growth and development. Dry matter production and photoassimilate translocation correlate positively with the productivity of the crop (Falqueto et al. 2009). Thus, the grain yield of a rice cultivar is determined by four components: (1) number of panicles per square meter, (2) number of spikelets per panicle, (3) spikelet fertility, and (4) mass of 100 grains (Santos, Stone, and Vieira 2006). Thus, based on the results obtained by the production components, the fall in grain yield occurred due to the decrease in the number of panicles and the mass of 100 grains (Table 6).

\section{Conclusions}

Our data allow us to infer that the reduction of soil acidity from $\mathrm{pH} 4.5$ to 6.3 decreased zinc and manganese contents in rice plants. We could also see that in general, NR enzyme activity was higher in plants grown on low-acidity soils ( $\mathrm{pH}$ 6.3) and fertilized with calcium nitrate. In addition, there was a higher development and productivity rate of the plants cultivated in soils with high acidity ( $\mathrm{pH} 4.5)$. On the other hand, in conditions of medium acidity ( $\mathrm{pH}$ 5.5), the plants cultivated with ammonium sulfate were more productive, and there were no differences with the addition of the nitrification inhibitor.

\section{Acknowledgement}

We are grateful to the FAPESP for the research funding (Processes: 2008/05641-6 and 2008/05573-0), CNPq for the research productivity grant granted to the second, third, fourth and fifth authors, and to Mr. Alex Knowles for English revision.

\section{ORCID}

Edemar Moro (D) http://orcid.org/0000-0001-7708-911X

Carlos Alexandre Costa Crusciol (D) http://orcid.org/0000-0003-4673-1071

Adriano Stephan Nascente (D) http://orcid.org/0000-0002-6014-3797

Heitor Cantarella (iD http://orcid.org/0000-0002-1894-3029

Fernando Broetto (D) http://orcid.org/0000-0002-8316-4144

Adriana Lima Moro (D) http://orcid.org/0000-0001-7708-911X

\section{References}

Araújo, J. L., V. Faquin, N. M. B. Vieira, M. V. C. Oliveira, A. A. Soares, C. R. Rodrigues, and A. C. Mesquita. 2012. Crescimento e produção do arroz sob diferentes proporções de nitrato e amônio. Revista Brasileira De Ciência Do Solo 36:921-30. doi:10.1590/S0100-06832012000300022.

Bvan, R., J. C. Andrade, H. Cantarella, and J. A. Quaggio. 2001. Análise química para avaliação da fertilidade de solos tropicais. Campinas: Instituto Agronômico.

Campbell, W. H. 1999. Nitrate reductase structure finction and regulation on bridging to gap between biochemistry and physiology. Annual Review of Plant Physiology and Plant Molecular Biology 580:277-303. doi:10.1146/annurev. arplant.50.1.277.

Celestino, J. C. 2006. Atividade da redutase do nitrato, em arroz cultivado em solo proveniente de áreas sob diferentes preparos, água e doses de nitrogênio. Thesis, Ilha Solteira, SP, Brazil: Universidade Estadual Paulista.

Crawford, N. M. 1995. Nitrate: Nutrient and signal for plant growth. The Plant Cell 7:859-68. doi:10.1105/tpc.7.7.859. 
Crusciol, C. A. C., A. M. Costa, E. Borghi, G. S. A. Castro, and D. M. Fernandes. 2010. Fertilizer distribution mechanisms and side dress nitrogen fertilization in upland rice under no-tillage system. Scientia Agricola 67:56269. doi:10.1590/S0103-90162010000500010.

Crusciol, C. A. C., R. A. Garcia, G. S. A. Castro, and C. A. Rosolem. 2011. Nitrate role in basic cation leaching under no-till. Revista Brasileira De Ciência Do Solo 35:1975-84. doi:10.1590/S0100-06832011000600014.

Crusciol, C. A. C., R. Soratto, A. S. Nascente, and O. Arf. 2013. Root distribution, nutrient uptake, and yield of two upland rice cultivars under two water regimes. Agronomy Journal 105:237-46. doi:10.2134/agronj2012.0298.

D’Andréa, A. F., M. L. N. Silva, N. Curi, and L. R. G. Guilherme. 2004. Estoque de carbono e formas de nitrogênio mineral em solo submetido a diferentes sistemas de manejo. Pesquisa Agropecuária Brasileira 39:179-86. doi:10.1590/S0100-204X2004000200012.

Epstein, E., and A. J. Bloom. 2006. Nutrição mineral de plantas: Princípios e perspectivas. Londrina, PR, Brazil: Planta.

Fageria, N. K. 2000. Upland rice response to soil acidity in cerrado soil. Pesquisa Agropecuária Brasileira 35:2303-07. doi:10.1590/S0100-204X2000001100024.

Fageria, N. K. 2014. Nitrogen management in crop production. Boca Raton: CRC Press.

Fageria, N. K., A. Moreira, and A. M. Coelho. 2011. Yield and yield components of upland rice as influenced by nitrogen sources. Journal of Plant Nutrition 34:361-70. doi:10.1080/01904167.2011.536878.

Fageria, N. K., A. Moreira, L. A. C. Moraes, and M. F. Moraes. 2014. Nitrogen uptake and use efficiency in upland rice under two nitrogen sources. Communications in Soil Science and Plant Analysis 45:461-69. doi:10.1080/ 00103624.2013 .861907$.

Fageria, N. K., N. A. Slaton, and V. C. Baligar. 2003. Nutrient management for improving lowland rice productivity and sustainability. Advances in Agronomy 80:63-152.

Falqueto, A. R., D. Cassol, A. M. Magalhães Júnior, A. C. Oliveira, and M. A. Bacarin. 2009. Partição de assimilados em cultivares de arroz diferindo no potencial de produtividade de grãos. Bragantia 68:453-61. doi:10.1590/S000687052009000300002 .

Flowers, T. H., and J. R. O'callaghan. 1983. Nitrification in soils incubated with pig slurry or ammonium sulphate. Soil Biology and Biochemistry 15:337-42. doi:10.1016/0038-0717(83)90080-9.

Galangau, F., F. Daniel-Vedele, and T. Moureaux. 1988. Expression of leaf nitrate reductase gene from tomato and tobacco in relation to light/dark regimes and nitrate supply. Plant Physiology 88:383-88. doi:10.1104/ pp.88.2.383.

Jaworski, E. G. 1971. Nitrate reductase assay in intact plant tissues. Biochemical and Biophysical Research Communications 43:1274-79. doi:10.1016/S0006-291X(71)80010-4.

Kluthcouski, J., A. L. Fancelli, D. Dourado Neto, C. M. Ribeiro, and L. A. Ferraro. 2000. Yield of soybean, corn, common bean and rice under no-tillage management. Scientia Agricola 57:97-104. doi:10.1590/S010390162000000100016.

Lange, A., J. L. N. Carvalho, V. Damin, J. C. Cruz, and J. J. Marques. 2006. Changes in soil properties due to application of nitrogen and straw in maize grown under no-till system. Ciência Rural 36:460-67. doi:10.1590/ S0103-84782006000200016.

Malavolta, E., G. C. Vitti, and S. A. Oliveira. 1997. Avaliação do estado nutricional de plantas: Princípios e aplicações, 2nd ed. Piracicaba: Potafos.

Nascente, A. S., C. A. C. Crusciol, and T. Cobucci. 2012. Ammonium and nitrate in soil and upland rice yield as affected by cover crops and their desiccation time. Pesquisa Agropecuária Brasileira 47:1699-706. doi:10.1590/ S0100-204X2012001200004.

Nascente, A. S., C. A. C. Crusciol, and T. Cobucci. 2013. The no-tillage system and cover crops - Alternatives to increase upland rice yields. European Journal of Agronomy 45:124-31. doi:10.1016/j.eja.2012.09.004.

Nascente, A. S., J. Kluthkouski, R. R. Rabelo, P. Oliveira, T. Cobucci, and C. A. C. Crusciol. 2011a. Upland rice yield under different soil management systems and nitrogen application times. Pesquisa Agropecuária Tropical 41:60-65.

Nascente, A. S., J. Kluthkouski, R. R. Rabelo, P. Oliveira, T. Cobucci, and C. A. C. Crusciol. 2011b. Upland rice cultivars development and yield regarding soil management. Pesquisa Agropecuária Tropical 41:189-92.

Oonyu, J. 2011. Upland rice growing: A potential solution to declining crop yields and the degradation of the Doho wetlands, Butaleja district-Uganda. African Journal of Agricultural Research 6:2774-83.

Pacheco, L. P., J. M. Barbosa, W. M. Leandro, P. L. O. A. Machado, R. L. Assis, B. E. Madari, and F. A. Petter. 2011. Biomass production and nutrient cycling of cover crops in upland rice and soybean. Revista Brasileira De Ciência Do Solo 35:1787-800. doi:10.1590/S0100-06832011000500033.

Saito, K., B. Linquist, G. N. Atlin, K. Phanthaboon, T. Shiraiwa, and T. Horie. 2005. Response of traditional and improved upland rice cultivars to N and P fertilizer in northern Laos. Field Crops Research 96:216-23. doi:10.1016/j. fcr.2005.07.003.

Santos, A. B., L. F. Stone, and N. R. A. Vieira. 2006. Rice crop in Brazil, 2nd ed. Santo Antônio de Goiás: Embrapa Arroz e Feijão.

Silva, F. C. 1999. Manual de análises químicas de solos, plantas e fertilizantes. Rio de Janeiro: Embrapa Solos. 
Ta, T. C., and K. Ohira. 1981. Effects of various environmental and medium conditions on the response of Indica and Japonica rice plants to ammonium and nitrate nitrogen. Soil Science and Plant Nutrition 27:347-55. doi:10.1080/ 00380768.1981.10431289.

Tisdale, S. I., W. I. Nelson, and J. D. Beaton. 1985. Soil fertility and fertilizers, 4th ed. New York: Macmillan.

Vincentz, M., T. Moureaux, and M. T. Leydecker. 1993. Regulation of nitrate and nitrite reductase expression in Nicotiana plumbaginifolia leaves by nitrogen and carbon metabolites. Plant Journal 3:313-24. doi:10.1111/j.1365313X.1993.tb00183.x. 